RACAR : Revue d'art canadienne

Canadian Art Review

\title{
New Art Histories: Severing the Incestuous Relation Between the Discipline and the Museum?
}

\section{Nicole Dubreuil}

Volume 28, 2001-2003

Art History Inside and Outside the University

L'histoire de l'art à l'université et hors de l'université

URI : https://id.erudit.org/iderudit/1069784ar

DOI : https://doi.org/10.7202/1069784ar

Aller au sommaire du numéro

\section{Éditeur(s)}

UAAC-AAUC (University Art Association of Canada | Association d'art des universités du Canada)

\section{ISSN}

0315-9906 (imprimé)

1918-4778 (numérique)

Découvrir la revue

Citer cet article

Dubreuil, N. (2001). New Art Histories: Severing the Incestuous Relation Between the Discipline and the Museum? RACAR : Revue d'art canadienne / Canadian Art Review, 28, 66-70. https://doi.org/10.7202/1069784ar

Tous droits réservés (C) UAAC-AAUC (University Art Association of Canada | Association d'art des universités du Canada), 2004
Ce document est protégé par la loi sur le droit d'auteur. L’utilisation des services d'Érudit (y compris la reproduction) est assujettie à sa politique d'utilisation que vous pouvez consulter en ligne.

https://apropos.erudit.org/fr/usagers/politique-dutilisation/ 


\title{
New Art Histories: Severing the Incestuous Relation Between the Discipline and the Museum?
}

\author{
NICOLE DUBREUIL, UNIVERSITÉ DE MONTREAL
}

The Panoptic Craze and the Society of Spectacle

$\mathrm{M}$ any authors have commented on the close link existing between the development of art history and the display of artefacts within the museum's walls. Some, like the French literary theoretician of realism, Philippe Hamon, have taken a broad epistemological overview that connects, under the general concept of "expositions", nineteenth-century architectural and discursive practices, linking them to the same cognitive system. Expanding on historian Pierre Nora's famous remark: "Il n'est de lieu que de mémoire" (every space is memory), Hamon points out that the most significant architectural realizations of the period, from the new department stores and the commercial arcades, to permanent and temporary exhibition pavilions, including the popular dioramas and panoramas, do not serve as mere décor - or containers - for redefined social behaviours. ${ }^{1}$ The architectural practice of what has been called "la société $d u$

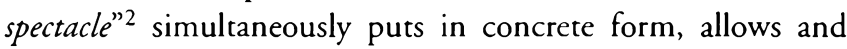
produces a conception of knowledge based on display, motivated by a phantasm of objective inquiry and exhaustive classification of all existing phenomena, each structure producing its own series - or sets of series - for intellectual grasp and/or pure enjoyment. This would also include the reassignment of older prestigious buildings like the Royal residency of the Louvre to the task of housing large art collections. Art history would then be the discursive exposition (meaning here the unfolding of textual argumentation) corresponding to the visual exposition of museum exhibits. Donald Preziosi takes a similar stance when he characterizes the modern epistémè as having been essentially museographic and art history as a kind of "major popular historical novel in and of museological space". ${ }^{3}$ Within the museographic paradigm, according to this author, both the museum and the discipline of art history as a set of practices and techniques contributed to a linking together of subjects and objects that became key operating components of the efficient functioning of the modern nation-state. Seemingly in agreement with Michel Foucault's conviction that every regime of knowledge is connected with a corollary regime of power, Preziosi designates the major European economic and political centres as masters of this game in which a panoptic frenzy becomes instrumental to both a scientific questioning of the world and the will to control it. That is why, among major manifestations of this state of affairs, the construction of non-Western culture within and by this pervasive museography (one may recall, here, Timothy Mitchell's reflection on orientalism and the exhibitionary order ${ }^{4}$ ) becomes the very instrument of colonial hegemony. As for history, that particular kind of knowledge concerned with displaying and understanding the past, it too, of course, is being elaborated from the point of view and for the interests of the present and of those commanding it.

\section{Propositions}

Keeping in mind this broad critical approach, my commentary will concentrate on more specific links between the discourse of the art museum and the discourse of art history. Trying to pay attention to both the conceptual and professional aspects of their relation and comparing their close-knit origin to the looser and more confused present state of affairs, it will organize its argument around museography as the production/exhibition of series - or seriation process - contending: 1) that the museographic effect pertaining to the museum can be characterized as having constituted a grand cognitive scenario in which every item gathered on the institution's premises is designated as belonging to a specific category labelled "art", and can thus be identified, classified and read (interpreted) by a process of comparison with other items of its kind; 2 ) that the grand cognitive narrative called art history and developed as an academic discipline on the premises of the university, because it has maintained the museum as its conceptual and professional horizon, remains largely faithful to this model of selection and devotes itself mainly to the writing of an autonomous history of the art series; 3) that recent trends in art history, under the influence of new critical paradigms coming from a multidisciplinary context and from certain practices of contemporary art, have acted mostly to destabilize this endogenous and fundamentally diachronic type of seriation to propose heterogeneous regrouping of representations (in which so-called art objects occupy no privileged position), operating synchronically in order to unravel diverse regimes of knowledge, power and subjectivity; 4) that these strategies may have severed the link between art history practiced in the universiry and art history enunciated by the museum, or at least rendered it problematic, even as they exercise pressure on the museum to make it alter its own positions; and 5) that these changes may in turn have created problems for the intellectual conduct of art history and for the professional identity of the art historian.

\section{The Museum: Art as a Natural Object}

Taking their impulse from the philosophical effervescence of the Enlightenment and the political turmoil surrounding the French Revolution, the museum and the discipline of art history as a subsidiary of the general discipline of history and of archeology gathered their momentum and established their au- 
thority in the course of the nineteenth century. Lyne Therrien, in her Ph.D. dissertation, now turned into a book, ${ }^{5}$ has shown that the first art history programmes in France officially started in the second half of the century and were simultaneously organized at the École du Louvre and in institutions of higher learning like the Sorbonne. It was clear from the start that the orientation of the new curricula had a lot to do with the museum's fields of expertise, an attitude that was somewhat indigenous to that country's tradition, since already in the seventeenth century Colbert had encouraged authors like Félibien and Testelin to develop their aesthetic systems of art evaluation from examples taken in the royal collections. Carol Doyon, in another Ph.D. dissertation concerning art historiography in nineteenth-century France, ${ }^{6}$ approached the problem from a different angle, that of book publication, and noticed the same type of affinities between the museum and the discipline, an affiliation that was to culminate, at the beginning of this century, in the publication of multi-volume "histoires générales de l'art" whose structure echoes that of the Louvre or, for that matter, that of any large Western museum (these important projects, among which one can point to André Michel's ambitious survey of the world's art, also happened to be collections in their own terms since they required the collaboration of many authors). The specifics, of course, may have varied from one European country to another, but I have neither the time nor the means to dwell on this here. Suffice it to recognize that one does, indeed, find both historical links and structural parallels between the writing of art history (whether they relate to academic programmes or to a genre of academic discourse) and the rooms en enfilade of major museums. But there is more to that collaboration. On a deeper level, one cannot consider how the historical investigation of what we conventionally call "art" could have been undertaken without the regrouping under one roof of large numbers of artefacts severed from their original functions and contexts of occurrence. To recall Foucault's criticism of historical essentialism, it was the museum that constructed "art" as a natural object, and thus enabled it to command its own aesthetic tradition in spite of the heterogeneous status (as linked to religious or civic rituals, decorations, etc.) of the particular objects subsumed under such a proper name. ${ }^{7} \mathrm{Com}$ paring history to a wasteland as opposed to a shooting range, the philosopher would certainly not have metaphorized it as a building either, so convinced was he of the imperviousness of the different regimes the notion is trying to encompass. So while the museum was creating the material and conceptual frame allowing us to envision objects aesthetically, our discipline was developing with the mission of putting into words the autonomous history of art. It is interesting to note how the contemporary rise of a new and powerful medium, that of photography which would eventually challenge the auratic quality of the art object, could not breach the sacred alliance just forming between the museum and the discipline. It just provided the first with virtual works to enlarge its own collections and gave the second access to a conventionally packaged musée imaginaire (museum without walls), a concept proposed by André Malraux, ${ }^{8}$ who was enthralled by the perspective of orchestrating a myriad of objects from all times and places into all kinds of regroupings: an anamorphic archive whose potential for seriation seemed endless, providing of course that the series remained endogenous.?

\section{The Humanistic Discipline}

So if we can safely recognize that the incestuous link between the museum and art history has shaped the discipline's discursive strategies, the methodological consequences of that situation still have to be examined more closely. While providing the art historian with a major professional horizon, the museum has in many ways made art history a subsidiary instrument to empirical connoisseurship whose main imperatives - identify and locate (in order, of course, to enjoy) - seem to define the task of the art specialist whether in the private office of the curator or in the public space of the classroom. Erwin Panofsky, reflecting on art history as a humanistic discipline, recognized this relation when he defined the connoisseur as a laconic art historian and the latter as a loquacious connoisseur. ${ }^{10}$ The connection has been more sensible in some aspects of art history programmes, either in terms of content (one thinks here of large survey courses) or in terms of procedure (when a detail, a work or a group of works are treated like the scene of a crime concealing traces of a perpetrating hand). Of course, the gigantic task of identification and classification, so congenial to the modernist epistémè, has now been largely accomplished - at least as it concerns the canon - and we may be ending up repeating ourselves by simply looking for new grounds to reapply the pattern. But there are other levels of our discourses that bear the imprint of the museum. In fact, every narrative that testifies to an autonomous development of art, whether formulated in terms of technique (medium), form (style) or content (iconography) becomes in one way or another a reiteration of the museographic paradigm. While all these aspects can point back to specific historical circumstances, the pressure remains high to treat them as mere background for internal strategies of repetition and change. Stylistic or formal analysis has proved especially vulnerable to a comparative game that bears the imprint of the museum's decontextualization and, as we have learned from Wölfflin, has shown a definite preference for scenarios of progress or cyclical returns. There may be some pertinence in glancing at the new art produced under this regime; we are thinking here of modernist painting and sculpture, and the 
formalist argument supporting them, as the very expression of the incestuous rapport with the museum. The huge abstract canvases produced by the American painters of the 1960s are a good case in point. Heralded by Greenbergian criticism as the transcendence, pure and simple, of the linear and pictorial styles of the past, ${ }^{11}$ these large coloured effigies, representing nothing but their own surfaces, depended to make their point on a double process of internal seriation: they came in groups (one could also add as in-groups), out of necessity, exploiting a specific formal problem that kept them from reverting to mere decoration; they also offered themselves as the teleological end products of a quest for the specificity of the medium ${ }^{12}$ that had motivated painting since Manet (Monet would also be a key figure concerning the question of the series). As flat as they pretended to be, flat like the neutral wall that would receive them as art, they opened up to a vertiginous temporal perspective for which they acted as the remarkable terminus ad quem. ${ }^{13}$ Because they were advocating their pure visuality, they also spoke of the brightly lit screen of the classroom and the slideshows of art history courses under the regime of the imaginary museum. If indifference to history other than its own was to be expected from this type of exacerbated formalism, this would of course be different with iconography. This method was, after all, ready to tackle the individual work in all its complex layers of meaning, passing from content to context, and aiming, if one takes Panofsky at his own definition of the iconological level, at a broad epistemological spectrum where "the basic artitude of a nation, a period, a class, a religious or philosophical persuasion" 14 could be expressed through the unconscious agency of one personality. Indeed, it amounted to an ambitious programme congenial with the kind of multi-disciplinary scholarship offered by the university. On top of that, the method sometimes relies as much on texts as it does on visual material; in the best cases, in which a structural analogy is drawn and not only source material sought, the method produces a hybrid circulation of references that could prove difficult to handle in a museum context. But we know that in practice (perhaps because it paid so much attention to the rebirth of classical antiquity in Renaissance culture) the Panofskian legacy has been particularly active on the iconographical level pure and simple, and especially interested in mapping out a diachronic circulation of motifs, from work to work, from period to period, that brings us back to the museum's display of the fine arts tradition.

\section{Regimes of Representations}

It seems, then, that the traditional practice of art history could not escape the museum paradigm. Why should it have done so, as long as both institutions remained ideologically and professionally attuned, the first turning out the specialists for the specialized field circumscribed by the second? Indeed, what the art museum continued to resist best, aside from paying lip service to it in occasional accompanying documents, was purveying any kind of historical context other than aesthetic. The disputes over the organization of the Musée d'Orsay and the final outcome of the project is a telling case for the present argument. Original propositions aimed at opening a dialogue between the art exhibited and the former train station housing it by including all kinds of material references (there was even talk of a locomotive) to the economic and socio-political contexts of the period covered by the collections. Of course, the actual museum has reverted to the more conventional art series; but ironically, the repressed context seems to have come back with a vengeance, the sculptures scanning the central alley reflecting more the taste of the Second Empire and Third Republic than presenting the landmarks of an autonomous history of the medium. The very fact that alternatives to the traditional modes of display could have been drawn up indicates a will for change and the rise of a critical attitude imputable to many agents. We know how some more radical aspects of modern and contemporary art since Duchamp have taken the museum as their target or have tried to leave it altogether for more open ground. But my interest here lies mainly with the practice of art history which, under the impulse of strong critical trends emerging within the human sciences, has tried to find new links between the texts of art and its contexts, including the relation between producer and receiver. If the good old Panofskian method had shown a keen awareness of different historical regimes of knowledge, the trend seems now to investigate the accompanying regimes of power and regimes of subjectivity as they are elaborated in a large array of representations, both verbal and non-verbal, and among which visual material coming from all sources - including the popular and mechanically reproduced - plays a key role. Putting art in context means in this case creating strongly heterogeneous series in which the specific history of a medium, of a genre or of a motif loses part of its importance in favour of a diachronic mapping of variations involving many different social agents. Of course, we identify the practice's most active proponents, at least in the Anglo-American tradition, with the social historians of art and people working in the new interdisciplinary fields of feminist, visual and cultural studies. My encounter with the former, a few decades ago, is worth recalling because it brings out the question of seriation which is my present object. Serge Guilbaut had organized a session of the annual Universities Art Association of Canada meeting at the Université du Québec à Montréal on something like modernism and politics, and I remember telling him, after hearing the speakers: "O.K. Serge, now I know what social art history is about: it's looking at bad art and old newspapers" (newspaper clippings had indeed been projected in large 
numbers on the screen). What was happening that prompted my reaction was not only a breaking up of the familiar art series but, it seems to me now, a different use of the photographic medium itself, showing its capacity to take and equalize anything submitted to its apparatus. Non-auratic photography could be, indeed, the strategic medium to shuffle the cards and stop the winning game of the art narratives, providing, of course, that it did not aim at imposing its own parallel history. Reflecting on the cataloguing process of the New York Public Library, Douglas Crimp was quite amazed - and frankly delighted - to find Edward Ruscha's artist book on Sunset Boulevard's gas stations stacked in the transportation section. He was distressed, on the other hand, by the librarian's project to regroup books from different disciplines illustrated by well-known photographers, under the pretext of constituting a collection and a history of photography. ${ }^{15}$

\section{Challenges Brought by the New Serials}

Coming to our museographic paradigm, we all have in mind more or less recent and more or less fruitful endeavours by museums trying to come to terms with the new pressure to "contextualize". The temptation has been strong, under the imperative of attracting larger crowds, to produce luscious settings, spectacular décors that are meant to recreate the feeling of a period while enhancing the aesthetic pleasure of the visitor. This strategy proved especially appealing for stylistic movements involving both fine and applied arts, like the numerous ramifications of Art Nouveau (one can think, for example, of the elaborate staging of the Vienna Exhibition ${ }^{16}$ ). Projects with a stronger critical edge have tackled head-on the relation between art and history to the point of displacing traditional hierarchies, or trying to do so. This seems to have been the case for periods with strong political determinants and less strong artistic identity, like Les années trente en Europe: Le temps menaçant, ${ }^{17}$ an exhibition held in Paris and Montreal in 1997 that dealt with the pre-War situation. Usually, these exhibitions rely on a principle of double or multiple seriations, forcing the art to face, or intermingle, with a rich array of visual and textual material (letters, books, posters, newsreel extracts, etc.). One of the most challenging of these exhibitions, Exilés \& Émigrés: The Flight of European Artists from Hitler, ${ }^{18}$ held at the Los Angeles County Museum in the same year as Les années trente and also brought to Montreal, dealt with the exodus towards the West of artists exposed to the Nazi regime. The very theme of the exhibition, the phenomenon of exile and its impact on artists (it corresponds to a field of research developed in Germany around the topic of Exilforschung), was meant to break with traditional museum practices. Among significant curatorial decisions, involving abundant documentary material, was the placing of a film on American immigration policies at the beginning of the exhibition, so that it would not be treated as an interlude and a resting space before going back to the more serious "stuff". On the other hand, the exhibition chose to follow the odyssey of well-known artists and presented on its walls only the canonical names of modernism from Surrealism to abstraction. In so doing, it ignored the very strategies of German artists in exile when, both in Paris and in London, they decided to regroup as exiles - and to include practitioners of broad affiliations and standards - to offer a widely encompassing presentation of the "other German art" as a response to Hitler's infamous Entartete Kunst exhibition. So, while the museum is struggling with the weight of its own past and with its over-determined architectural spaces, art history's "musée imaginaire" may be at last in a position to sever itself from the museographic paradigm and start playing a different game. It has, after all, the capacity to explore all kinds of new seriations that can unfold freely on the classroom's screens with traditional and new projection devices. Moreover, the discipline may be seen as reinforcing its ties with the university not only because it borrows so many critical concepts from other disciplines, but because it is often called to join larger interdisciplinary units like Visual Studies, Cultural Studies or Feminist Studies (here budget cuts may play a role, as I shall point out in my last example). None the less, in spite of this promising openness, one has to admit that the present situation remains far from creating a clear-cut difference between museum art history and academic art history. On the one hand, art history carries its own traditional weight embodied in individuals (colleagues and their fields of expertise), structures (programmes), and material equipment (existing slide collections); besides, some of the proposed new series end up being rather conventional in nature in so far as they aim only to expand, with previously ignored or repressed material, the traditional existing art series (this was the case with many studies on women's art or, for that matter, with studies on the art of all kinds of minorities - postcolonial or not - eager to find a legitimate place in history, even if these practices have significantly unsettled the canonical categories and definitions). As for the more challenging ventures into unknown territories and hybrid seriations, those that interest me here and that are concerned with a very broad array of cultural representations (most of which are usually not classifiable as "art"), they may bring about unforeseen problems. One of these is theoretical, and I will only evoke it briefly here. In spite of the conviction that the concept of an autonomous history of "art" has to be revised drastically, I cannot but register the ensuing loss that this situation creates when it comes to treating this particular artefact called the art object within a context of multiple representations evaluated for their historical agency or ideological resonance. "Art" representations, at least since the Renaissance, have acted 
within and often against a strongly endogenous tradition commanding technical, formal and iconographical practices which can easily be ignored (flattened out) when comparisons are made "across the board" between representations of multiple origins and media. Frequently, these comparisons will stop at the immediate level of content - producing no more than a kind of revisited iconography. For many years, I have worked on what I have ironically called "le pateux", that is on the actual (if any) theoretical status of paint application in painted images, when these images are examined in a broader historical context. Aside from these methodological speculations, I want to conclude by considering a totally different challenge, this time professional, facing our present situation. Art history under the museographic paradigm seems to have had a well defined, if in some ways restricted, professional horizon: it produced "art" specialists. The question then arises: what shall we be producing now? In a colloquium entitled "Où val'histoire de l'art contemporain?"19 organized in Paris, a few years ago, by a team of historians and art historians defining themselves as a "groupe de recherche sur l'image fixe", Rosalind Krauss reacted strongly to the creation of what she found a non-motivated object - still images - that was symptomatic of the present trend to despecialize old humanistic disciplines well entrenched in academic curricula. She felt that with the ongoing pressure to cut university budgets, the first targets of administrators would probably be these new interdisciplinary critical spaces, however prestigious they thought themselves to be. I was at the time neither impressed nor convinced by what I saw as another outburst of American imperialism. But, to my surprise, we had to resort to the same argument in my own department, when colleagues from comparative literature, a small but theoretically strong graduate programme (in fact, they seem more concerned with theory than with specific literary traditions), under the menace of being closed down as a department, asked to join our administrative unit already composed of art history, cinema and fine arts. Intellectually, many of us found the project appealing: it would in the long run create a space to deal with representations at large, examine cross-cultural exchange, maintain a critical edge, etc. Yet, we refused in the end mainly for professional reasons, not to lose our specificity and our proper name, both of which, unfortunately, are still tied to the museographic paradigm and to the status of art as our "objet naturel". I guess this could be defined as an aporia.
Notes

1 Philippe Hamon, Expositions. Littérature et architecture au XIXe siècle (Paris, 1989), 9.

2 Guy Debord, La Société du spectacle (Paris, 1967).

3 Donald Preziosi, "The Art of Art History," in his The Art of Art History: A Critical Anthology (Oxford, 1998), 509.

4 Timothy Mitchell, "Orientalism and the Exhibitionary Order," in Preziosi, The Art of Art History, 455-72.

5 Lyne Therrien, L'Histoire de l'art en France. Genèse d'une discipline universitaire (Paris, 1998). See also her article in the present issue: "L'Institutionnalisation de l'histoire de l'art en France au XIXe siècle".

6 Carol Doyon, De l'Exemple à l'archive. La constitution des discours sur l'art du passé, en France, entre 1850 et 1900, Ph.D. diss., Concordia University, 1995.

7 For an analysis of Foucault's deconstruction of the "natural object", see Paul Veyne, "Comment Foucault révolutionne l'histoire", in his, Comment on écrit l'histoire (Paris, 1978).

8 André Malraux, Le Musée imaginaire de la sculpture mondiale (Paris, 1952).

9 Discussed in Donald Preziosi, Rethinking Art History: Meditations on a Coy Science (New Haven, 1989).

10 Erwin Panofsky, "The History of Art as a Humanistic Discipline" (1940), in Art History and Its Methods, ed. Eric Fernie (London, 1995), 194.

11 Clement Greenberg, "After Abstract Expressionism," Art International (June 1963).

12 After Greenberg's famous argument developed in his no less famous essay "Modernist Painting", Arts Yearbook, 4 (1961).

13 After another famous argument by Rosalind Krauss, "A View of Modernism," Artforum (September 1972).

14 Erwin Panofsky, Studies in Iconology: Humanistic Themes in the Art of the Renaissance (New York, 1962), 7.

15 Douglas Crimp, On the Museum's Ruins (Cambridge, 1995), $77-81$.

16 Vienne, 1880-1938: L'apocalypse joyeuse, exh. cat., Centre Georges Pompidou (Paris, 1986).

17 Les années trente en Europe. Le temps menaçant, exh. cat., Musée d'art moderne de la Ville de Paris (Paris, 1997).

18 Exilés \& Emigrés: The Flight of European Artists from Hitler, exh. car., Los Angeles County Museum of Arr (Los Angeles, 1997).

19 École supérieure nationale des beaux-arts (Paris, 1995). 